\title{
Mining in a changing climate: what scope for forestry-based legacies?
}

Article

Accepted Version

Creative Commons: Attribution-Noncommercial-No Derivative Works 4.0

Hirons, M., Hilson, G., Asase, A. and Hodson, M. (2014)

Mining in a changing climate: what scope for forestry-based legacies? Journal of Cleaner Production, 84. pp. 430-438. ISSN 0959-6526 doi:

https://doi.org/10.1016/j.jclepro.2013.11.025 Available at https://centaur.reading.ac.uk/44175/

It is advisable to refer to the publisher's version if you intend to cite from the work. See Guidance on citing.

To link to this article DOI: http://dx.doi.org/10.1016/j.jclepro.2013.11.025

Publisher: Elsevier

All outputs in CentAUR are protected by Intellectual Property Rights law, including copyright law. Copyright and IPR is retained by the creators or other copyright holders. Terms and conditions for use of this material are defined in the End User Agreement.

\section{www.reading.ac.uk/centaur}

\section{CentAUR}

Central Archive at the University of Reading 
Reading's research outputs online 


\title{
Mining in a Changing Climate: What scope for forestry-based legacies?
}

\author{
Mark Hirons ${ }^{a}$, Gavin Hilson ${ }^{b}$, Alex Asase ${ }^{c}$, Mark E Hodson ${ }^{d}$ \\ a School of Agriculture, Policy and Development, The University of Reading, \\ Earley Gate, P.O. Box 237, Reading RG6 6AR,UK \\ ${ }^{b}$ The Surrey Business School, Faculty of Business, Economics and Law, University of Surrey, Guildford, \\ GU2 $7 X H, U K$ \\ ${ }^{c}$ Department of Botany, University of Ghana, P. O. Box LG 55 Legon, \\ ${ }^{\mathrm{d}}$ Ghana Environment Department, University of York, York, YO10 5DD, UK
}

\begin{abstract}
This paper provides an interdisciplinary perspective on mine reclamation in forested areas of Ghana, a country characterised by conflicts between mining and forest conservation. A comparison was made between above ground biomass (AGB) and soil organic carbon (SOC) content from two reclaimed mine sites and adjacent undisturbed forest. Findings suggest that on decadal timescales, reclaimed mine sites contain approximately $40 \%$ of the total carbon and $10 \%$ the AGB carbon of undisturbed forest. This raises questions regarding the potential for decommissioning mine sites to provide forestry-based legacies. Such a move could deliver a host of benefits, including improving the longevity and success of reclamation, mitigating climate change and delivering corollary enumeration for local communities under carbon trading schemes. A discussion of the antecedents and challenges associated with establishing forest-legacies highlights the risk of neglecting the participation and heterogeneity of legitimate local representatives, which threatens the equity of potential benefits and sustainability of projects. Despite these risks, implementing pilot projects could help to address the lack of transparency and data which currently characterises mine reclamation.
\end{abstract}

Key Words: Mining, Reclamation, Land-use Change, Forest-legacies, Carbon Finance 


\section{Introduction}

Prompted by criticisms regarding poor environmental and social performance, the global mining industry has implemented a comprehensive sustainable development agenda. This agenda is becoming increasingly dominated by concerns over climate change, widely recognised as one of the most important challenges of the $21^{\text {st }}$ century (Stern, 2006). Mining corporate sustainability strategies, therefore, have increasingly engaged with the issues of carbon emissions mitigation and carbon accounting (Pellegrino and Lodhia, 2012). The emergence of strategies to manage carbon emissions from land-use change presents an opportunity for mining companies to augment their sustainability credentials by using carbon finance to support reclamation of mined land to forests, ${ }^{1}$ and the economic development of local host communities. Although some companies have started to engage with payment for ecosystem services (PES) schemes (Olsen et al., 2011), the potential for forestry-based legacies has received limited attention (Gilberthorpe and Banks, 2012). It is timely, therefore, to critically review the basis for, and implications of, such schemes.

Drawing on interdisciplinary research conducted in Ghana, this paper aims to gauge the potential for forest-based legacies by providing an initial quantification of the carbon stocks associated with reclamation in forest areas, exploring how key stakeholders understand and influence the reclamation of mine sites, and reflecting on the potential implications of mining companies harnessing carbon finance as part of their sustainability strategies. The findings suggest that forestry-based legacies could go a long way towards mitigating the adverse socio-ecological impacts associated with unplanned and poorly executed mine closures (Laurence, 2007). The discussion also highlights how the global focus on climate change risks marginalising the concerns of local communities and exacerbating the already-inequitable sharing of natural resource-derived benefits. Nonetheless, pursuing pilot projects would help to address the lack of data and transparency that currently characterises mine reclamation in countries such as Ghana.

\section{Sustainable Mining: The Growing Importance of Climate Change}

From one perspective, sustainable mining is an oxymoron: exploiting a finite resource is inherently unsustainable. But the mining industry provides a range of materials essential for societal wellbeing. Accordingly, most accusations that the mining industry is unsustainable are directed not at the industry per se, but at the corollary impacts which contradict key sustainability principles, especially environmental protection and the equity of economic growth.

The economic benefits of mining are well noted, but are rarely realised in local 'host' communities which, instead, bear the brunt of the problems associated with mineral extraction and processing. The academic and popular literature is replete with examples of unsustainable practices in the mining industry, including unmitigated land degradation and deforestation, chemical leakages, water pollution and human rights abuses (Ballard and Banks, 1997; Ruggie, 2007; Bebbington and Bury, 2009). These issues are particularly prevalent in developing countries, which have competed for investment by, inter alia, creating favourable tax incentives and minimising regulatory oversight (Akabzaa, 2004). Although the general applicability of the 'race to the bottom' theory in the context

\footnotetext{
${ }^{1}$ Mine reclamation refers to the process of returning mined land to a useful state, which in the context of this paper is a forest for the purpose of sequestering and storing carbon.
} 
of a globalising mining sector is open to debate (Konisky, 2007), there is widespread agreement that resource-rich countries have consistently underperformed economically and environmentally. This 'resource curse' is evidenced by several mineral-rich countries' perpetual occupation of the lowest tier of the UN Human Development Index, and topping Transparency International's Corruption Perceptions Index.

In response to widespread criticism, the mining industry has pursued a series of legitimising strategies in order to operationalise a rhetorical shift towards 'sustainable mining' (Whitmore, 2006). Corporate Social Responsibility (CSR) agendas are at the forefront of these strategies. As Gilberthorpe and Banks (2012) point out, the underlying justification for the adoption of CSR is that it provides a framework for delivering sustainable development. Reflecting the growing importance of climate change in the sustainable development discourse (Grist, 2008), the mining industry has, rather sluggishly, begun to engage with the issue. The production of a suite of documents on climate and mining by the International Council on Mining and Minerals (ICMM) which aims to demonstrate the willingness of the industry to play 'a constructive and pragmatic role in climate change policy discussions' (ICMM, 2013) is symptomatic of this shift.

The most recent ICMM climate reports, released in May 2013, focus, understandably, on articulating the physical and financial risks associated with climate change and carbon pricing. This focus reflects the increasingly neoliberal approach to sustainable development encapsulated by the commodification of carbon and the promotion at the Rio+20 conference of the 'green economy'. Under this paradigm, payment for ecosystem services (PES) schemes rooted in the carbon market have proliferated. Such schemes enable individuals, government, non-governmental organisations and private companies to pay for carbon storage and sequestration (Kinzig et al., 2011). Several variants of carbon-based PES schemes exist, including the poorly-regulated voluntary carbon market (Gillenwater et al., 2007), the Clean Development Mechanism (CDM) created under the Kyoto Protocol, and Reducing Emissions from Deforestation and Degradation (REDD+ ${ }^{2}$ ). Policy-makers have embraced carbon finance schemes because they ostensibly deliver both environmental benefits in the form of increased carbon storage, and financial benefits to poor communities and countries. It has been estimated that carbon markets could be potentially worth more than US\$30billion/year (Corbera et al., 2010).

There is considerable concern, however, that carbon market initiatives are being pursued in spite of the considerable risks associated with introducing policies which are not sufficiently grounded in the realities of the contexts in which they are being implemented. Boyd (2009) argues that while proven scientific methods exist for quantifying carbon dynamics associated with land-use change, scientists and resource managers simplify complex forest ecosystems and their social context in order to facilitate universal management strategies, including the trading of carbon credits. Furthermore, the commodification of carbon risks reversing advances in decentralised and community-based natural resource management (Sandbrook et al., 2010). This resurgent protectionism (Beymer-Farris and Bassett, 2012) threatens to undermine local institutions, complicate resource tenure and marginalise community control over resource management and decision-making, factors which have been found to be necessary components of PES projects that contribute to poverty alleviation and environmental protection (Dougill et al., 2012).

\footnotetext{
2 The 'plus' component of REDD+ refers to the enhancement of carbon stocks, sustainable forest management with respect to forest communities and biodiversity conservation.
} 
The relatively low-spatial extent of mining activities means the sector has received less attention than agriculture and logging in carbon-market and PES discussions. But, by virtue of their extensive concessions and dramatic impact on ecosystems, mining companies represent a significant land holder and a key stakeholder in land-use governance. Although the ICMM document 'The role of Mining and Metals in Land-Use and Adaptation' (ICMM, 2013) moots involvement of the mining industry with REDD+, there has been little discussion regarding how and why mining companies might engage with land-use based carbon finance initiatives ${ }^{3}$. Principally, schemes are viewed as a carbon offset option, with companies providing the finance for projects (ICMM, 2013). Schemes of this kind have begun to emerge. In Madagascar, for example, Rio Tinto is collaborating with the International Union for Conservation of Nature (IUCN) on a project aiming to utilise PES schemes to support conservation in order to offset their activities (Olsen et al., 2011).

A more direct link between mining activities and carbon markets could be established through forest-based legacies. Under such schemes, mined land could be reclaimed to forest and then returned to communities which could derive benefits through payments for carbon sequestration under the voluntary carbon market, the CDM, or, if negotiations allow, under the plus-component of REDD+ schemes. In theory, these schemes could augment CSR agendas by contributing to the mitigation of climate change and local development. Sperow (2006), for example, highlights the potential of carbon sequestration on mine sites by estimating that in the United States, rehabilitating mined areas could contribute up to $12.5 \%$ of a $7 \%$ target reduction in total emissions. The potential for carbon-based PES schemes at mine sites in a development context, however, has not received any explicit attention.

This paper contributes to debates by examining the potential for, and potential pitfalls of, forestbased legacies. A balanced analysis requires a holistic approach which develops an understanding of the carbon dynamics of reclaimed mine sites as well as accounting for the complex social realities and contested nature of resource governance which typifies mining-forestry contexts. The following section outlines the interdisciplinary methods used in this study to provide an initial estimate of the progress of reclamation in restoring forest carbon stocks and investigate how reclamation is conceptualised by a variety of stakeholders.

\section{Materials and Methods}

Land-use change and resource management is not merely a technical exercise, but requires an interdisciplinary approach to understand the diverse drivers and dynamics of natural resource governance. Supported by critical realist philosophy, this study utilises methods deriving from natural science as well as more reflexive and interpretive data collection required to elucidate the complexity of social systems. Ghana is an illustrative case to examine because of the importance of mining to its national economy, the subsequent prevalence of mining in the High Forest Zone (HFZ), and the country's pursuit of improved forest management policies, including REDD+ (Hilson and Nyame, 2006; Hansen et al. 2009).

\footnotetext{
${ }^{33}$ Mining companies have, however, been involved with energy related carbon market schemes, notably the European Union Emissions Trading Scheme.
} 
To ascertain an estimate for the success of carbon stock restoration, carbon stocks were calculated at reclaimed mine sites and compared with those at adjacent forests and, where possible, farmland. Only above ground biomass and soil organic carbon pools were considered in this study as they represent the most significant carbon pools and neglecting other pools, such as litter or deadwood, is permissible in policy-orientated studies provided that doing so produces a conservative estimate (Grassi et al., 2008). Differences between carbon stored under different land-uses were tested with Analysis of Variance (ANOVA) and a posthoc Tukey's test for pairwise comparisons using the statistics package SPSS. The data were gathered from fieldwork undertaken between December 2011 and August 2012.

\subsection{Study Sites}

During a reconnaissance visit to Ghana in April 2011 and liaisons with key government officials, national NGOs and mining companies, two areas were selected for the study. In Obuasi, in the Ashanti Region of the country, AngloGold Ashanti is mining gold in the Supuma Forest Reserve and has a relatively well established reclamation scheme. Due to challenges with accessibility in Supuma, forest carbon stock data were also collected from the Atewa Forest reserve in the Eastern Region. In the Western Region, Kinross Chirano is also operating a gold mine in the Tano Suraw Forest Reserve, where it has begun reclamation.

At each of the sites, $0.25 \mathrm{ha}(25 \mathrm{~m} \times 25 \mathrm{~m})$ plots were established at regular intervals along transects established on reclaimed sites and juxtaposing forest-land and, where possible, farmland. These transects ranged in length, due to the variation in size of reclaimed plots, from $100 \mathrm{~m}$ to $2 \mathrm{~km}$. Correspondingly, intervals between plots, which were approximately equidistant from each other, ranged from $50 \mathrm{~m}$ to $500 \mathrm{~m}$, depending on transect length. In total, plots were sampled from four forested areas, seven reclaimed sites and two areas of farmland. As Chave et al. (2004) explain, twenty 0.25 ha plots are necessary to establish a robust estimate of above-ground biomass at a landscape scale. Fewer sites are required for smaller areas, such as reclaimed sites, and so as many plots were sampled as reasonably practical. In total, 69 bulk density samples and 279 soil organic carbon (SOC) samples were collected. The sites and sampling are summarized in Table 1.

\subsection{Above Ground Biomass and Carbon Stocks}

Within each plot, diameter at breast height (DBH, 1.3m above ground level) was measured on all trees with $\mathrm{DBH}>5 \mathrm{~cm}$. The above ground biomass (AGB) for each tree was estimated using Chave et al.'s (2005) generalised allometric equation. With the assistance of Ghana Forestry Commission staff, trees were identified to species level allowing for wood specific gravities - a required input for Chave et al.'s (2005) allometric equations - to be ascertained using the World Agroforestry Database ${ }^{4}$ and Simpson (1996). Where trees could not be identified, or densities for species could not be found, the mean density for the plot or the mean density for the same genus was used, which is a good predictor of species wood density (Chave et al., 2006). By convention, AGB is converted to carbon stocks by multiplying by 0.5 (e.g. Glenday, 2006).

\footnotetext{
${ }^{4}$ Available at: http://www.worldagroforestry.org/Sea/Products/AFDbases/wd/ [25.06.13]
} 


\subsection{Soil Organic Carbon Stocks}

Samples for calculating SOC content were collected at sites using an auger to $1 \mathrm{~m}$ depth in $20 \mathrm{~cm}$ sections (summarized in Table 1). Air dried soils were returned to the UK, where they were gently sieved to remove shoots, roots and the $>2 \mathrm{~mm}$ coarse fraction ${ }^{5}$. The proportion of soil organic matter (SOM) was ascertained using the loss-on-ignition (LOI) method (Rowell, 1994). Briefly, 10g subsamples were dried overnight at $105^{\circ} \mathrm{C}$, weighed, and then placed in a $500^{\circ} \mathrm{C}$ muffle furnace, cooled in a desiccator and then weighed again. The proportion of weight loss from the soil represents the SOM content in the sample. Although $\mathrm{LOI}$ at $500^{\circ} \mathrm{C}$ can drive off structural water contained in clays and inorganic constituents such as carbonates and therefore lead to overestimates of SOM (Rowell, 1994), the relatively large number of samples taken and low cost of the method makes it suitable for this study (Robertson et al. 1999). The SOM content was converted to SOC content by using a factor of 0.58 (Guo and Gifford, 2002).

\footnotetext{
${ }^{5}$ The $>2 \mathrm{~mm}$ fraction is composed primarily of stones, gravels
} 
Table 1. Summary of site details and data collected. Longitude and latitude (ddd-mm format) are given for the start of each transect, followed by transect length and direction. Where AGB is absent, no plots were established and soil samples were collected along the transects. The maximum depth of augers at each site is provided. Bulk Density (BD) pits are to a depth of $1 \mathrm{~m}$ unless otherwise stated.

\begin{tabular}{|c|c|c|c|c|c|c|c|}
\hline Area & Site & Description & $\begin{array}{l}\text { Transect } \\
\text { Location | Length | Direction }\end{array}$ & $\begin{array}{l}\text { Approx. } \\
\text { Area }\end{array}$ & $\begin{array}{l}\text { AGB } \\
\text { sampling }\end{array}$ & SOC sampling & BD sampling \\
\hline \multirow[t]{6}{*}{ Obuasi } & $\begin{array}{l}\text { Obuasi } 10 y r \\
\text { reclaimed }\end{array}$ & $\begin{array}{l}\text { Waste dump reclaimed } \\
\text { for } 10 \text { years }\end{array}$ & $\begin{array}{l}\text { N06 10.492 W001 } 40.541 \text { | } \\
\text { 300m | West-East (W-E) }\end{array}$ & 50ha & 3 plots & $\begin{array}{l}6 \text { augers, up } \\
\text { to } 60 \mathrm{~cm}\end{array}$ & $\begin{array}{l}1 \mathrm{BD} \text { pit, to } \\
25 \mathrm{~cm}\end{array}$ \\
\hline & $\begin{array}{l}\text { Obuasi } 5 \text { yr } \\
\text { reclaimed }\end{array}$ & $\begin{array}{l}\text { Mining area reclaimed } \\
\text { for } 5 \text { years }\end{array}$ & $\begin{array}{l}\text { N06 } 12.751 \text { W001 } 39.084 \text { | 250m | } \\
\text { South-North (S-N) }\end{array}$ & 50ha & 3 plots & $\begin{array}{l}6 \text { augers, up } \\
\text { to } 100 \mathrm{~cm}\end{array}$ & $\begin{array}{l}1 \mathrm{BD} \text { pit, to } \\
40 \mathrm{~cm}\end{array}$ \\
\hline & $\begin{array}{l}\text { Obuasi } 4 \text { yr } \\
\text { reclaimed }\end{array}$ & $\begin{array}{l}\text { Mining area reclaimed } \\
\text { for } 4 \text { years }\end{array}$ & $\begin{array}{l}\text { N06 } 12.751 \text { W001 } 39.084 \text { | 250m | } \\
\text { S-N }\end{array}$ & 30ha & 3 plots & $\begin{array}{l}6 \text { augers, up } \\
\text { to } 200 \mathrm{~cm}\end{array}$ & $\begin{array}{l}1 \mathrm{BD} \text { pit, to } \\
40 \mathrm{~cm}\end{array}$ \\
\hline & $\begin{array}{l}\text { Obuasi nat. } \\
\text { Reclaimed }\end{array}$ & $\begin{array}{l}\text { Naturally reclaimed (un- } \\
\text { reclaimed) mining area. }\end{array}$ & $\begin{array}{l}\text { N06 } 12.644 \text { W001 39.202 | 200m | } \\
\text { W-E }\end{array}$ & 20ha & - & $\begin{array}{l}5 \text { augers, up } \\
\text { to } 20 \mathrm{~cm}\end{array}$ & No BD \\
\hline & $\begin{array}{l}\text { Obuasi farm } \\
\text { control site }\end{array}$ & Farmland Control Site & $\begin{array}{l}\text { N06 14.214 W00135.669 | 300m | } \\
\text { S-N }\end{array}$ & $50 \mathrm{ha}$ & $*$ & $\begin{array}{l}6 \text { augers, up } \\
\text { to } 180 \mathrm{~cm}\end{array}$ & $1 \mathrm{BD}$ pit, repeat \\
\hline & $\begin{array}{l}\text { Obuasi forest } \\
\text { control }\end{array}$ & $\begin{array}{l}\text { Forest adjacent to } \\
\text { Obuasi } 10 \text { years site }\end{array}$ & $\begin{array}{l}\text { N06 10.512 W001 } 40.623 \text { | 100m | } \\
\text { E-W }\end{array}$ & 40ha & $* *$ & $\begin{array}{l}3 \text { augers, up } \\
\text { to } 80 \mathrm{~cm}\end{array}$ & No BD \\
\hline \multirow[t]{5}{*}{ Chirano } & $\begin{array}{l}\text { Exploration Park } \\
\text { site }\end{array}$ & $\begin{array}{l}\text { Mining area reclaimed } \\
\text { for } 7 \text { years }\end{array}$ & $\begin{array}{l}\text { N06 } 18.582 \text { W002 22.787 | 200m | } \\
\text { N-S }\end{array}$ & 10ha & 2 plots & $\begin{array}{l}5 \text { augers, up } \\
\text { to } 160 \mathrm{~cm}\end{array}$ & $\begin{array}{l}1 \mathrm{BD} \text { pit to } \\
80 \mathrm{~cm}\end{array}$ \\
\hline & Suraw Pond site & $\begin{array}{l}\text { Mining area reclaimed } \\
\text { for } 3 \text { years }\end{array}$ & $\begin{array}{l}\text { N06 17.244 W002 22.563 | 200m | } \\
\text { E-W }\end{array}$ & 10ha & 2 plots & $\begin{array}{l}3 \text { augers up to } \\
120 \mathrm{~cm}\end{array}$ & $\begin{array}{l}1 \mathrm{BD} \text { pit to } \\
40 \mathrm{~cm}\end{array}$ \\
\hline & $\begin{array}{l}\text { Chirano Tano } \\
\text { Waste site }\end{array}$ & $\begin{array}{l}\text { Mining area reclaimed } \\
\text { for } 4 \text { years }\end{array}$ & $\begin{array}{l}\text { N06 } 18.330 \text { W002 } 23.097|100 m| \\
\text { E-W }\end{array}$ & 1ha & 1 plot & $\begin{array}{l}3 \text { augers, up } \\
\text { to } 80 \mathrm{~cm}\end{array}$ & No BD \\
\hline & $\begin{array}{l}\text { Tano suraw Forest } \\
\text { reserve }\end{array}$ & $\begin{array}{l}\text { Forest reserve under } \\
\text { mining concession }\end{array}$ & $\begin{array}{l}\text { N06 } 19.995 \text { W002 22.458 | 300m | } \\
\text { S-N }\end{array}$ & 200ha & 2 plots & $\begin{array}{l}3 \text { augers, up } \\
\text { to } 100 \mathrm{~cm}\end{array}$ & No BD \\
\hline & $\begin{array}{l}\text { Tano Suraw } F \text {. } \\
\text { reserve extension }\end{array}$ & $\begin{array}{l}\text { Forest reserve under } \\
\text { mining concession }\end{array}$ & $\begin{array}{l}\text { N06 } 20.032 \text { W002 22.339 | 300m | } \\
\text { W-E }\end{array}$ & 300ha & 3 plots & $\begin{array}{l}5 \text { augers, up } \\
\text { to } 100 \mathrm{~cm}\end{array}$ & $1 \mathrm{BD}$ pit, repeat \\
\hline \multirow[t]{2}{*}{ Kibi } & $\begin{array}{l}\text { Atewa Forest } \\
\text { Reserve }\end{array}$ & Forest reserve & $\begin{array}{l}\text { N06 14.010 W000 33.100 | 2km | W-E } \\
\text { N06 10.021 W000 36.240 | 1km | W-E }\end{array}$ & 23,663ha & 5 plots & $\begin{array}{l}18 \text { augers up } \\
\text { to } 200 \mathrm{~cm}\end{array}$ & $\begin{array}{l}3 \text { BD pits. with } \\
\text { repeats }\end{array}$ \\
\hline & Atewa Control site & $\begin{array}{l}\text { Farmland adjacent } \\
\text { Atewa forest reserve }\end{array}$ & $\begin{array}{l}\text { N06 14.010 W000 33.100 | 2km | W-E } \\
\text { N06 10.021 W000 36.240 | } 1 \mathrm{~km} \mid \mathrm{W}-\mathrm{k}\end{array}$ & $50 h a$ & $*$ & $\begin{array}{l}6 \text { augers, up } \\
\text { to } 100 \mathrm{~cm}\end{array}$ & $\begin{array}{l}3 \text { BD samples up } \\
\text { to } 20 \mathrm{~cm}\end{array}$ \\
\hline
\end{tabular}

*Farmland AGB from literature

** Obuasi forest AGB estimate from aggregate other forest sites sampled 
To calculate absolute SOC values, soil bulk density (BD) was measured using the core method (Grossman and Reinash, 2002). Samples were taken using a small $(4.5 \times 4.7 \mathrm{~cm})$ core at $20 \mathrm{~cm}$ intervals in pits dug to $1 \mathrm{~m}$. At sites where bulk density pits were not as deep as the augers, due to the presence of rocks, the bulk density from the layer above was used (Hughes et al. 2002). This is suitable in policy-orientated carbon research as, assuming bulk density increases with depth, it provides a conservative estimate.

Cores were ground and sieved to remove the $>2 \mathrm{~mm}$ fraction and oven dried at $105^{\circ} \mathrm{C}$. The BD was calculated by dividing the oven dry mass of the sample by the volume of the core. As Throop et al. (2012) explain, this calculation is appropriate for studies of soil carbon because the $>2 \mathrm{~mm}$ fraction is predominantly composed of stones, gravel and coarse sands and, therefore, contains little or no carbon. Total soil carbon stocks $\left(\mathrm{SOC}_{\mathrm{t}}\right)$ in each layer were calculated as follows:

$$
\mathrm{SOC}_{\mathrm{t}}=\mathrm{SOC}_{\mathrm{c}} \times \mathrm{BD} \times \mathrm{L} \times 10^{2}
$$

Where

- $\mathrm{SOC}_{\mathrm{t}}=$ Total soil organic carbon stocks $(\mathrm{Mg} \mathrm{C} \mathrm{ha-1})$

- $\mathrm{SOC}_{\mathrm{c}}=$ Concentration of soil organic carbon (\%)

- $\mathrm{BD}=$ Bulk Density $\left(\mathrm{g} \mathrm{cm}^{-3}\right)$

- $\mathrm{L}=$ depth of layer $(0.2 \mathrm{~m})$

\subsection{Identifying and exploring relevant social factors}

In addition to the quantitative component of the study, a series of exploratory semi-structured interviews were conducted with key stakeholders. These included Environment and Community Managers at mining companies $(n=5)$; national and district officers at the Ghana Minerals Commission $(n=4)$, the national mining policy-making body; representatives from District Assemblies, the country's local government bodies ( $n=7)$; Traditional Authorities ( $n=5)$; and local resource users $(n=10)$. Participants were selected by snowball sampling after initial contact had been made with key stakeholders identified through the reconnaissance visit in April 2011 and a review of the literature. The interviews were designed to identify factors which are relevant to the reclamation of mine sites, and therefore included exploring the perspectives of stakeholders on the impact of mining on forests, the perceived success of reclamation, the characteristics of the relationships between mining companies and their host communities, and existing challenges to reclamation.

\section{Results}

\subsection{Reclamation: discourses of discontent}

Before reviewing the carbon stocks associated with reclamation in Ghana, it is illustrative to outline the key debates on mining and forestry in the country, which revolve around a dualism concerning reclamation. On the one hand, governments and mining companies propound that activities are controlled through adherence to the numerous laws, policies and guidelines which regulate mining in forested areas. On the other hand, critics of the industry contend that enforcement and 
monitoring of laws is weak, and communities convey dissatisfaction regarding the operations of mining companies by encroaching on reclaimed areas to farm.

There are more than 20 laws, policies and guidelines which form the basis of the formalised mining regulatory framework but its key constituents include the Environmental Guidelines for Mining in Productive Forest Reserves in Ghana, 2001; Forest and Wildlife Act (currently being updated), 1994; Environmental Impact Assessment Procedures (1995); Environmental Regulations (LI 1652), 1999; and the recently updated Minerals and Mining Act, 2006. Mining companies, the Minerals Commission and advocates of the industry refer to these documents and their directives to argue that mining is strictly controlled. As one environmental manager explained in an interview:

Our operations have been guided by some regulations and guidelines. We also have what we call the Ghana Liaison group which is multidisciplinary in character... We are envisaging [successful reclamation], as we have stated in the EIAs [Environmental Impact Assessments], some of the pits will be back-filled, top soil and re-planting; but this will be done in consultation with the communities and the forest services division.

According to one EPA official interviewed, mining companies promote the idea that their activities are 'non-additional' ${ }^{6}$ - that is, because companies are strictly controlled and mandated to reclaim land, their net impact is zero. This position assumes reclamation leads to a full restoration of carbon stocks. But this is strongly contested by many critics of the industry, who argue that reclamation cannot replace forests and that the EIA process is undermined by a lack of transparency and community involvement. One NGO officer echoed these sentiments in an interview:

At reclaimed sites, you can see that some trees have been planted, but no one's doing assessment of what species are there and how well this reclamation is restoring land to its original landscape... It [reclaimed land] becomes a plantation and that is it, the natural forest will never come back... The people that can question the EIA and its findings are the locals, and they are often illiterate, have no internet and most do not even read the dailies [newspapers]. The EPA [Environmental Protection Agency] display the EIA on their website, sometimes, and in the newspaper, but it is often in some small insignificant corner near the back. The locals don't even see the EIA, let alone question it.

A District Assembly officer from a village adjacent to a mine highlighted similar concerns, explaining in an interview that 'There's forests all around the village, but they can't farm on the forest because the soil is bad...[and] they are foreign trees specially brought in because they can survive in the area and on the poor soil'.

Although this point is supported by studies on mine soils (Ussiri and Lal, 2005) at some sites, communities were observed farming on reclaimed sites. This poses considerable concern to companies, as one Environmental Manager at a large-scale mine articulated during an interview:

But here, what most people do is that they enter into our re-vegetated areas, cut the shrubs or the trees that we have planted indiscriminately for use as firewood, or fuelwood. And in the end, they tend to disrupt our programme. So, to tell you in all honesty, we believe

\footnotetext{
${ }^{6}$ Additionality is a key concern of carbon-market initiatives and it refers to the requirement that carbon funds should not support activities which would have happened anyway.
} 
without community interference, or community getting themselves into our rehabilitated areas, we would be able to succeed, but as it stands now, it's really difficult.

The polarised nature of debates regarding the reclamation of mining in forested areas of Ghana accentuates the lack of data in the area. However, the analysis also highlights the notion that reclamation is not merely a technical issue concerning the efficacy of regulations and reclamation techniques, but is rather also contingent on local politics. The following section outlines the results from the investigation into the progress of restoration of carbon stocks, before reflecting on the potential implications of forest-based legacies.

\subsection{Reclaiming mine sites: restoring carbon stocks?}

Growing concerns over climate change have precipitated an enthusiastic pursuit of strategies aimed at reducing deforestation and enhancing forest carbon stocks. Mining companies keen on promoting their sustainable development credentials have flirted with PES schemes, such as REDD+. The potential for forest-based legacies to harness the carbon market to deliver environmental and social benefits has heightened interest in carbon stocks associated with reclaimed mined land and forests. As the previous section outlined, in Ghana, mining companies and government officials contend that reclamation can successfully restore carbon stocks. The results from this study partially support that position. They show that while reclaimed mined sites contain significantly less $(\rho<0.05)$ carbon than forests and farmland, on decadal timescales, they restore approximately $10 \%$ of the $A G B$, and $50 \%$ of the SOC. Forests sampled in the study contained a mean of $236( \pm 48 \mathrm{n}=10)^{7} \mathrm{Mg} \mathrm{C}^{-1}$ in $\mathrm{AGB}$, and $727( \pm 37 \mathrm{n}=5) \mathrm{Mg} \mathrm{Cha}^{-1}$ in soils to a depth of $1 \mathrm{~m}$, or a total of $963( \pm 48 \mathrm{n}=6) \mathrm{Mg} \mathrm{C}^{-1}$. Reclaimed sites contained a total of $403( \pm 31 \mathrm{n}=6) \mathrm{MgCha}^{-1}$, approximately $40 \%$ of the carbon contained in forests (Figure 1). ${ }^{8}$ The variability between reclamation sites, however, supports the widely-held view that reclamation is poorly monitored and enforced. Furthermore, the findings of this study challenge the widespread neglect of soil carbon in policy processes and highlight the importance of site management.

\footnotetext{
${ }^{7}$ Figures in parenthesis throughout show the standard error of the mean.

${ }^{8}$ Estimates for AGB carbon align with those presented in the literature (e.g. Tan et al., 2009; Wade et al., 2010) and those for SOC align with studies using similar methods (Amponsah and Meyer, 2000). Several studies (Wauters et al., 2008; Usuga et al., 2010; Wade et al. 2010) consider soil to a depth of $15-30 \mathrm{~cm}$ and use the Walkley-Black method which tends to underestimate SOC content, but extrapolating their results suggests more reasonable estimates for SOC to $1 \mathrm{~m}$ lie in the range of $150-330 \mathrm{Mg} \mathrm{C}$ ha-1. The use of the loss-on-ignition method in this study may have led to an overestimation of soil carbon stocks; future analysis using dry combustion (Sollins et al. 1999) would help constrain these uncertainties.
} 


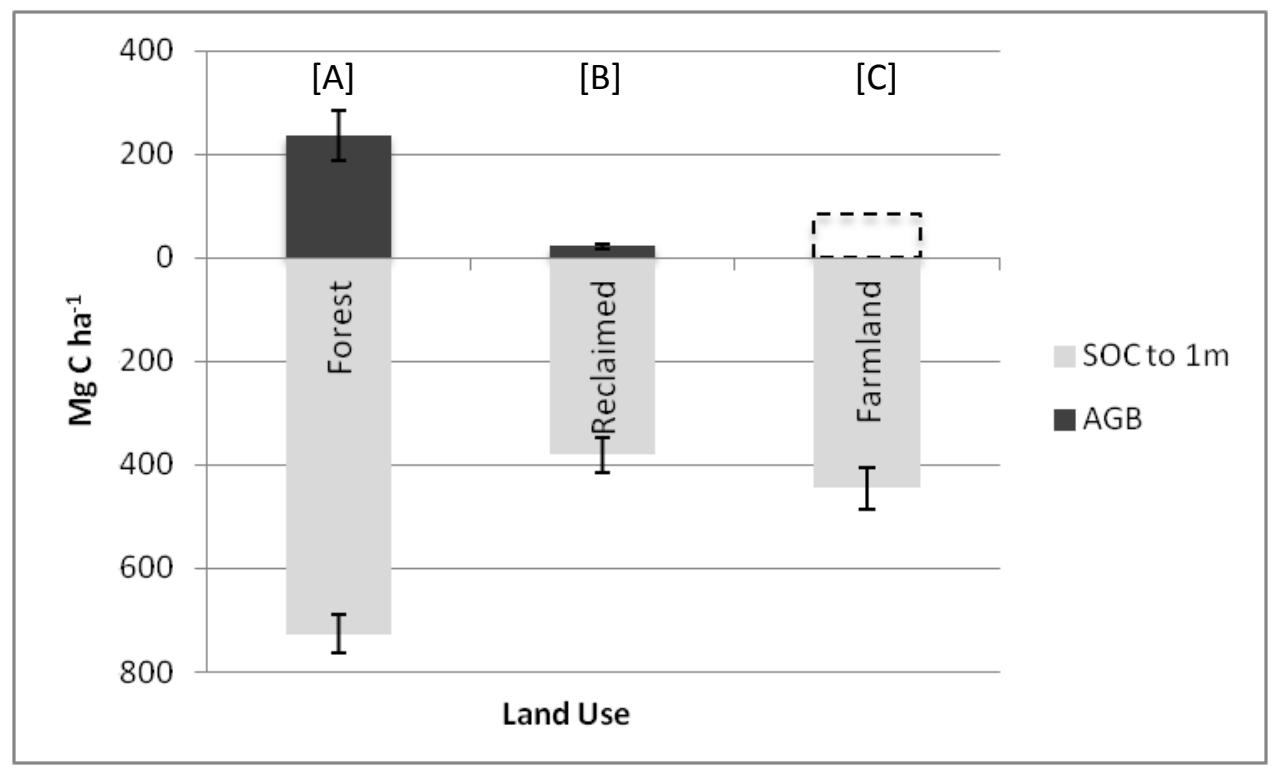

Figure 1. Mean carbon stocks in above ground biomass (AGB) and soil organic carbon (SOC) under different land-uses in Ghana. Upper case letters show significant differences $(\rho \leq 0.05)$ using a Tukey's test, figures with the same letter are not significantly different for total carbon. Error bars show standard errors of the mean (Forest $A G B n=10$ SOC $n=5$, Reclaimed $A G B n=14$ SOC $=5$, Farmland SOC $n=5$ ). AGB figure for farmland taken from Wade et al. (2010) and represents an estimated mean average carbon stock for cocoa farmland.

\subsubsection{Aboveground carbon}

Samples gathered from reclaimed sites in Obuasi and Chirano were dominated by Cedrela odorata L., Terminalia ivorensis A.Chev. and Acacia auriculiformis A. Cunn. ex Benth., species selected for their hardiness in poor soils and fast growth rates. Very few native species were recorded during sampling; the most frequently occurring was Ceiba pentrandra L. Gaertn., which appeared on three plots at Chirano (total reclaimed plots $n=14$ ). This supports the NGO-led argument that reclaimed land does not restore the original forest, but simply leads to the creation of a plantation.

Plots at reclaimed sites contained more trees (with DBH $>5 \mathrm{~cm}$ ) than forested plots (an average of 67 compared with 49), while reclaimed sites contained significantly less $(\rho=0.01)$ AGB carbon than forested sites. Reclaimed sites stored, on average, $22( \pm 5 n=14) \mathrm{MgCha}^{-1}$, compared with $236( \pm 48$ $\mathrm{n}=10) \mathrm{Mg} \mathrm{C}$ ha $^{-1}$ for sampled forests. At Chirano, where AGB was sampled from reclaimed sites and adjacent forest reserves, carbon stocks were higher than average, with reclaimed land containing 31 $( \pm 11 \mathrm{n}=5) \mathrm{Mg} \mathrm{C} \mathrm{ha}^{-1}$ and Tano Suraw Forest Reserve 303 ( $\left.\pm 5 \mathrm{n=5}\right) \mathrm{Mg} \mathrm{Cha}^{-1}$. Proportionally, both the aggregate and site-specific results suggest that reclaimed sites in Ghana contain about $10 \%$ of the $A G B$ carbon found in forested land.

As sites mature, however, this proportion will increase. Table 2 shows that even the oldest sites have been reclaimed relatively recently - within 7 and 10 years at Chirano and Obuasi, respectively. Apart from the Tano Waste site (4 years) at Chirano ${ }^{9}$, older sites generally contain more AGB than younger sites. Furthermore, at some sites, such as the 5 -year reclaimed site at Obuasi, up to $50 \%$ of the trees were $<5 \mathrm{~cm}$ DBH. Using the method employed here, carbon stocks at reclaimed sites are likely to

\footnotetext{
${ }^{9}$ Which was a small site (less than $50 \times 50 \mathrm{~m}$ ) which meant only one AGB plot was established.
} 
increase sharply as numerous trees reach $5 \mathrm{~cm}$ DBH at about the same time due to their similar age. The considerable degree of variability between sites prevents any statistically meaningful conclusions from being drawn regarding the rate of carbon sequestration. The difference between the Obuasi 5-year and 10-year plots, for example, is significant $(\rho=0.05)$, but the Obuasi 4-year plot contains more AGB carbon than the 5 year site.

The variability among sites suggests that the management of reclaimed sites has a significant influence over the relative success of establishing trees. This conclusion is highlighted further when considering that the 'naturally reclaimed' site at Obuasi contained no trees with $\mathrm{DBH}>5 \mathrm{~cm} .{ }^{10}$ There are several management factors which influence the success of reclamation, most notably, the application of fertilizer, mulching, liming, topsoil storage and application, and species selection, including the use of bio-remediating plants (Shrestha and Lal, 2006). These factors are also critical in the restoration of soil carbon stocks.

\subsubsection{Soil Organic Carbon}

For the most part, SOC dominates carbon storage at reclaimed sites. Approximately $88-99 \%$ of the carbon stored at reclaimed sites is contained within the soil. This reinforces findings presented by Shrestha and Lal (2010), who show that soil carbon represented the major proportion (94\%) of total carbon at reclaimed sites, especially during the early stages. In terms of carbon content, forested land adjacent to the Obuasi 10-year site had an average of 5.2\% ( $\pm 0.49 \mathrm{n}=6) \mathrm{SOC}$, compared to $3.7 \%$ $( \pm 0.30 n=52)$ at the reclaimed site. This difference was greater in soils at the Chirano mine and the Tano Suraw Forest Reserve, where SOC content was $2.6 \%( \pm 0.1 n=48)$ and $4.5 \%( \pm 0.2 n=34)$ respectively. The average $\mathrm{SOC}$ content for farmland was similar (statistically insignificant) to reclaimed sites at $3.1 \%( \pm 0.18 n=42)$.

Despite dominating carbon stocks at reclaimed sites, reclaimed soils contained significantly less $(\rho=$ 0.01 ) carbon than forest soils and farmland soils. They contain approximately $50 \%$ of forest carbon stocks and $85 \%$ of the carbon contained in farmland soils (Figure 1). The carbon stored at reclaimed sites, unlike growth in AGB, cannot simply be equated to carbon sequestration, however, as the soils have been imported from elsewhere. Only growth in carbon stocks over time should be considered as sequestration. Baseline studies of reclamation sites are, therefore, imperative components of a more comprehensive assessment of the carbon dynamics associated with mining, and a necessary step toward facilitating the inclusion of reclamation schemes under PES schemes.

\footnotetext{
${ }^{10}$ The naturally reclaimed site also had extremely thin $(0-10 \mathrm{~cm})$ soils, which would also inhibit the establishment of trees in the longer-term.
} 
Table 2. Summary of carbon stocks at reclaimed mine sites with years since reclamation. Aggregate forest carbon column shows the mean carbon stock from all forests sampled. All soil data to $1 \mathrm{~m}$ unless otherwise stated. Figures in parenthesis show standard errors of the mean.

\begin{tabular}{|c|c|c|c|c|c|c|c|c|c|c|c|c|}
\hline \multirow{4}{*}{$\begin{array}{l}\bar{n} \\
\frac{0}{7} \\
0 \\
0\end{array}$} & $\begin{array}{l}\text { Mean Bulk } \\
\text { Density }\left(\mathrm{g} \mathrm{cm}^{-3}\right)\end{array}$ & & & & $\begin{array}{l}1.44( \pm 0.27 \\
\mathrm{n}=2) \text { to } \\
40 \mathrm{~cm}\end{array}$ & $\begin{array}{l}1.36( \pm 0.20 \\
\mathrm{n}=2) \text { to } \\
40 \mathrm{~cm}\end{array}$ & & & & & $\begin{array}{l}1.03( \pm 0.14 \\
\mathrm{n}=2) \text { to } \\
40 \mathrm{~cm}\end{array}$ & $\begin{array}{l}1.23( \pm 0.07 \\
n=36)\end{array}$ \\
\hline & SOC (\%) & & & & $\begin{array}{l}3.4( \pm 0.18 \\
n=23)\end{array}$ & $\begin{array}{l}2.7( \pm 0.24 \\
n=17)\end{array}$ & & & & & $\begin{array}{l}3.7( \pm 0.30 \\
n=12)\end{array}$ & $\begin{array}{l}5.9( \pm 0.17 \\
n=152)\end{array}$ \\
\hline & AGB (Mg C ha-1) & & & & $14( \pm 2 n=3)$ & $10( \pm 2 n=3)$ & & & & & $27( \pm 5 n=3)$ & $\begin{array}{l}236( \pm 48 \\
n=10\end{array}$ \\
\hline & Soil C (Mg C ha-1) & & & & $\begin{array}{l}524( \pm 13 \\
n=5)\end{array}$ & $\begin{array}{l}338( \pm 28 \\
n=5)\end{array}$ & & & & & $\begin{array}{l}211( \pm 22 \\
n=3) \text { to } \\
60 \mathrm{~cm}\end{array}$ & $\begin{array}{l}727( \pm 37 \\
n=5)\end{array}$ \\
\hline \multicolumn{2}{|c|}{$\begin{array}{l}\text { YEARS SINCE } \\
\text { RECLAMATION }\end{array}$} & 1 & 2 & 3 & 4 & 5 & 6 & 7 & 8 & 9 & 10 & $\begin{array}{l}\text { Aggregate } \\
\text { Forest }\end{array}$ \\
\hline \multirow{4}{*}{ 号 } & Soil C (Mg C ha-1) & & & $\begin{array}{l}442( \pm 23 \\
n=5)\end{array}$ & $\begin{array}{l}353( \pm 15 \\
n=5)\end{array}$ & & & $\begin{array}{l}217( \pm 11 \\
n=5)\end{array}$ & & & & \\
\hline & AGB (Mg C ha-1) & & & $6( \pm 4 n=2)$ & $66(n=1)^{*}$ & & & $39( \pm 1 n=2)$ & & & & \\
\hline & SOC (\%) & & & $\begin{array}{l}2.2( \pm 0.15 \\
n=16)\end{array}$ & $\begin{array}{l}3.5( \pm 0.18 \\
n=9)\end{array}$ & & & $\begin{array}{l}2.5( \pm 0.22 \\
n=23)\end{array}$ & & & & \\
\hline & $\begin{array}{l}\text { Mean Bulk } \\
\text { Density }\left(\mathrm{g} \mathrm{cm}^{-3}\right)\end{array}$ & & & $\begin{array}{l}2.03( \pm 0.01 \\
\mathrm{n}=2) \text { to } \\
40 \mathrm{~cm}\end{array}$ & & & & $\begin{array}{l}0.88( \pm 0.06 \\
\mathrm{n}=4) \text { to } \\
80 \mathrm{~cm}\end{array}$ & & & & \\
\hline
\end{tabular}

* Tano Waste Site only had 1 plot as the area was very small. 
The Obuasi farmland control site contained $582( \pm 28 \mathrm{n}=5) \mathrm{Mg} \mathrm{Cha}{ }^{-1}$ in the soil to $1 \mathrm{~m}$ and SOC content was $3.5 \%( \pm 0.2 n=22)$. While the content (\%) falls within estimates for reclaimed sites, the higher bulk density at the site $\left(1.75 \mathrm{~g} \mathrm{~cm}^{-3} \pm 0.03 \mathrm{n}=10\right)$ means that stocks are significantly $(\rho=0.05)$ higher than the 5 - and 10-year reclaimed sites, but not the 4-year reclaimed site, which contained $524( \pm 13 n=5) M g C h a^{-1}$. This highlights, first and foremost, the importance of bulk density for carbon stock estimates, and secondly, the potential for reclamation to restore soil carbon stocks relatively quickly, provided that soil is stored adequately during the extraction phase of mining.

Bulk density on reclaimed sites varies greatly, from $2.03( \pm 0.01 \mathrm{n}=2) \mathrm{g} \mathrm{cm}^{-3}$ at the Chriano 3-year site to $0.88( \pm 0.06 \mathrm{n}=4) \mathrm{g} \mathrm{cm}^{-3}$ at the 7 -year site. The findings demonstrate, non-significantly, that bulk density tends to decrease on reclaimed sites with increasing age. This reinforces findings reported by Shrestha and Lal (2010), who contend that it is due to a reversal of heavy compression during the act of reclamation. This reduction in bulk density over time suggests that, although in general, older plots have higher SOC content, total SOC stocks may decline over time. This is contingent on the eventual fate of SOC, as soils decompress: if the soils thicken, then total storage will increase, but this complicates policy-orientated research which requires variables such as depth to be treated consistently. Despite the challenges associated with developing robust data on soil carbon at reclaimed sites, the results presented here lead to broadly similar conclusions to those drawn regarding AGB carbon. Reclamation can partially restore carbon stocks, but differences between site-specific characteristics and management have a significant impact on the success of reclamation and lead to variable outcomes.

\subsection{Summary: indeterminate success but definite potential}

The results presented here show that, on decadal timescales, reclamation restores approximately $40 \%$ of soil carbon stocks and $10 \%$ of carbon in AGB. These figures lend weight to proponents of the mining industry who argue that, given time, reclamation can restore carbon stocks. They could also, however, be used by critics of the industry who contend that reclamation only effectively creates plantations, and even with a consistent growth rate, reclamation would only restore approximately $50 \%$ of the carbon over a 50-year period. The limited and uneven nature of the restoration and lack of biodiversity augments arguments that reclamation cannot be successful. Evidently, the challenges associated with the management of mine reclamation, and land-use change more generally, are not resolved merely through the provision of scientific data. The inherent judgement required in interpreting scientific results and their implications mean that this contention holds true even under decreasing levels of uncertainty.

Nonetheless, the results demonstrate the potential of reclaimed sites to sequester carbon, particularly into degraded soils, and accordingly, they could be integrated with carbon-finance schemes. In terms of AGB, while the results do not indicate a clear relationship between carbon stocks and length of reclamation, some crude 'back of the envelope' calculations can be performed which highlight the potential financial benefits. Dividing average AGB carbon stocks at reclaimed sites (22 Mg Cha-1) by average length of time since reclamation (5.5 years) indicates that carbon stocks at reclaimed sites grow by approximately $4 \mathrm{MgCha}^{-1} \mathrm{yr}^{-1}$. Converting this to tonnes of $\mathrm{CO}_{2}$ 
equivalents ${ }^{11}$ provides an effective sequestration rate of $14.68 \mathrm{t} \mathrm{CO}_{2} \mathrm{ha}^{-1} \mathrm{yr}^{-1}$. The value of this sequestration evidently depends on the price of carbon; at US\$7/tCO $\mathrm{CO}_{2} \mathrm{e}$, this sequestration would be worth US\$104 per hectare ${ }^{12}$. Having contextualised debates regarding reclamation in Ghana and highlighted the potential for forest-based legacies, the following discussion reflects on the challenges associated with such schemes.

\section{Discussion: 'Growing' Gold on Reclaimed Mine Sites?}

The emergence of carbon finance schemes, such as the CDM and REDD+, have put the issues of forestry-based legacies on the sustainable mining agenda. Carbon finance could potentially be used to incentivise community cooperation with reclamation efforts which would help realise the benefits, including carbon sequestration, which intact and healthy forests provide. There are, however, several issues which should temper enthusiasm for forest-based legacies, including science and data issues, the scope of community participation, and the potential exacerbation of existing conflicts.

Fry (2008) highlights how issues of permanence, measurement, additionality and, importantly, the establishment of baselines threaten to undermine the carbon market. The results from this study point to the challenge these issues present to forest-based legacies, particularly in relation to soil carbon. Although soils at reclaimed sites contain significant amounts of carbon, the process of importing soils for reclamation makes establishing a base-line a fundamental requirement for establishing pilot projects. Furthermore, the variability shown in reclaimed-mine soils also reinforce well-articulated concerns regarding accurately determining carbon sequestration on policy relevant (5-year) timescales (see Jandl et al., 2007).

In the mining sector, problems regarding data availability are potentially more soluble than in other industries. The inclusion of carbon monitoring under existing EIA and Environmental Management Plans could yield broader and more robust data. However, existing concerns regarding the lack of transparency and community involvement in the EIA process raises broader concerns regarding the potential participation of communities in forest-legacy schemes.

Ostrom's (2009) work on the decentralisation of forest resources demonstrates that forestry projects are most likely to deliver benefits both in terms of carbon sequestration and community development when decision-taking, rule-making and enforcement are decentralised and undertaken by the community. The possibility of carbon finance projects reversing a broad trend towards decentralised and community-based natural resource management is a critical concern (Sandbrook et al., 2010; Beymer-Farris and Bassett, 2012). In the case of carbon-market initiatives on reclaimed mine land, however, communities are typically alienated from the land. Even modest community involvement in projects, therefore, would represent a positive step towards decentralised control over land-use.

\footnotetext{
${ }^{11}$ By multiplying by 3.67 (Matthews, 2008)

${ }^{12}$ The price of a Gold Standard carbon credit on the 18 June 2013 was $\$ 7.26$ (5.5 Euros - Carbon Trade Exchange)
} 
Similarly, supporting reclamation circumvents concerns regarding the neglect of biodiversity in carbon-based conservation (Putz and Redford, 2009). Although forest-based legacies cannot fully restore the biodiversity of natural forests, and should perhaps be termed 'plantation-based legacies', compared to un-reclaimed land, they offer a host of benefits. This contention supports Edwards et al. (2010), who argue that enhancement of forest carbon stocks can increase biodiversity, decrease the conversion of land to agriculture and provide employment opportunities to local communities.

The potential benefits related to forestry-based legacies, however, are contingent on building a productive and co-operative relationship between mines and their communities. Without community participation and commitment, the long-term and continuous process of monitoring and managing the area is unlikely to occur (Dougill et al., 2012). But as noted previously, the enclave nature of mineral development in many parts of the world has led to generally poor relationships between mining companies and 'host' communities. The complaints made by a District Assembly man during an interview typify the difficulties experienced by communities:

Initially the relationship was good, but more recently, things have gone downhill. They do underground blasting which affects our borehole, the water is now polluted and the blasting is also making cracks appear in the houses... the company has built us a school, but there are no staff quarters and so we cannot attract teachers to come here.

The paternalistic relationship which characterises many mine-community relationships is exacerbated by the tendency for companies to treat populations as homogeneous entities. In one mining area where a village was being relocated to make way for mining, another assembly man complained in an interview about how the community was not adequately represented as the company dealt exclusively with the village chief:

...and it is not only the consultants that don't speak in favour of the community, the household chief too is not in favour of them. He has cars, he has money, he has five houses, but he was just a poor guy here before. He is an illiterate but now he has become rich, he has been paid by the company and was awarded a contract to manage security, even though he is illiterate! He even has someone there doing the writing for him and everything.

If companies continue to overlook the heterogeneity of host communities, exacerbate local elite capture and ignore the de facto leaders, then mine-community relationships are unlikely to improve and forestry-based legacies are destined to fail. This issue is particularly relevant when considering the distribution of benefits. The risk of local elite capture and corruption within carbon-market projects is well noted (Brown, 2010), and the distribution of benefits would require careful monitoring if carbon finance schemes are not going to exacerbate conflicts over natural resources. Clarifying ownership of land, trees and carbon is an essential component of mitigating conflicts over potential forestry projects on mine sites. Although this issue has been raised under REDD+ (Asare, 2010) to date, little progress has been made.

These political issues attenuate enthusiasm for potential projects and, if they remain unresolved, are likely to become manifest in a lack of permanence and increased conflicts. Forestry-based legacies, therefore, entail a degree of reputational risk to companies which might be reluctant to sponsor ostensible 'green-washing'. Whilst different interest groups will inevitably continue to pursue their own agendas, there is at least one laudable feature to schemes of this nature: they open up the 
work of the company directly to scrutiny. Unlike the case of Rio Tinto's 'offset' scheme in Madagascar (Olsen et al., 2011), which distracts from the direct impacts of the company, forestrybased legacy schemes could increase transparency and help to generate data in an area where a lack of information fosters polarised and poorly-informed debates.

\section{Concluding remarks}

Climate change is a fringe consideration in the mining industry, but nascent attempts to engage with the carbon market have highlighted the potential for forest-based legacies to provide a host of benefits. For proponents of the carbon market, mining companies represent a potential initial source of funding for small-scale reforestation projects which often find it difficult to attract investment (Boyd et al. 2007). To mining companies, harnessing carbon finance to support forestry-based reclamation and legacy projects augments CSR agendas by contributing to mitigation of climate change and local development.

Although uncertainties remain in quantifying the potential benefits, the results presented here and the spatially-widespread presence of mining operations in tropical forest regions suggests that forest-based legacies constitute a potentially-valuable option for both mining companies and their host communities. The global focus of climate change concerns, however, threatens to marginalise local concerns. Of particular relevance for potential forestry-based legacies is the need to account for the diversity of legitimate representatives of local communities and how they can equitably participate in managing projects. Combined with questions regarding the tenure of carbon, trees and land at reclaimed mine sites, this issue is foundational to the likely equity of benefit-sharing.

The potentially inequitable sharing of benefits from forestry-based legacies threatens to exacerbate local resource conflicts and the permanence of projects, undermining the delivery of both climaterelated and developmental benefits. Although there is plenty of scope for pessimism regarding forest-legacies, the institution of pilot projects can hardly be expected to worsen mine-community relations, which are typified by mistrust and mutual detriment. Furthermore, pursuing such a strategy would help to address the dearth of data and lack of transparency that generally characterises mine reclamation in countries such as Ghana.

\section{Acknowledgements}

The authors wish to thank Atta for his assistance in the field, the participants for their time and cooperation and three reviewers who helped improve the paper. This research was funded by a NERC-ESRC interdisciplinary studentship. An earlier version of this research was presented at the $2^{\text {nd }}$ UMaT International Mining and Minerals Conference held in Tarkwa, August 2012. 


\section{References}

Akabzaa, T., 2004. African Mining Codes a Race to the Bottom. Third World Network, Penang. Available online: http://www.choike.org/nuevo eng/informes/2400.html [Accessed: 18.06.13].

Amponsah, I., Meyer, W., 2000. Soil Characteristics in Teak Plantations and Natural Forests in Ashanti Region, Ghana. Communications in Soil Science and Plant Analysis. 31, 355-374.

Asare, R.A., 2010. Implications of the Legal and Policy Framework for Tree and Forest Carbon in Ghana: REDD Opportunities Scoping Exercise. Katoomba Incubator - Forest Trends, Nature Conservation Research Centre, Accra, Ghana. Available online: http://www.foresttrends.org/documents/files/doc 2452.pdf [25.06.13].

Ballard, C. Banks, G., (Eds.), 1997. The Ok Tedi Settlement: Issues, Outcomes and Implications. National Centre for Development Studies and Resource Management, Canberra, Australia.

Bebbington, A.J., Bury, J.T., 2009. Institutional challenges for mining and sustainability in Peru. Proceedings of the National Academy of Sciences. 106, 17296-17301.

Beymer-Farris, B.A., Bassett, T.J., 2012. The REDD menace: Resurgent protectionism in Tanzania's mangrove forests. Global Environmental Change. 22, 332-341.

Boyd, E, Gutierrez, M., Chang, M., 2007. Small-scale forests carbon projects: Adapting CDM to lowincome communities. Global Environmental Change. 17, 250-259.

Boyd, E., 2009. Governing the clean development mechanism: global rhetoric verses local realities in carbon sequestration projects. Environment and Planning A. 41, 2380-2395.

Brown, M., 2010. Limiting Corrupt Incentives in a Global REDD Regime. Ecology Law Quarterly. 37, 237-267.

Chave, J., Andalo, C., Brown, S., Cairns, M.A., Chambers, J.Q., Eamus, D., Fölster, H., Fromard, F., Higuchi, N., Kira, T., Lescure, J-P., Nelson, B.W., Ogawa, H., Puig, H., Riéra, B., Yamakura, T., 2005. Tree allometry and improved estimation of carbon stocks and balance in tropical forests. Oecologia. $145,87-99$.

Chave, J., Condit, R., Aguilar, S., Hernandez, A., Lao, S., Perez, R., 2004. Error propagation and scaling for tropical forest biomass estimates. Phil. Trans. R. Soc. Lond. B. 359, 409420.

Chave, J., Muller-Landau, H.C., Baker, T.R., Easdale, T.A., Ter Steege, H., Webb, C.O., 2006. Regional and phylogenetic variation of wood density across 2456 neotropical tree species. Ecol. Appl. 16, 2356-2367.

Corbera, E., Estrada, M., Brown, K., 2010. Reducing Greenhouse Gas Emissions from Deforestation and Forest Degradation in Developing Countries: Revisiting the Assumptions. Climatic Change. 100, DOI: 10.1007/s10584-009-9773-1.

Dougill, A.J., Stringer, L.C., Leventon, J., Riddell, M., Rueff, H., Spracklen, D.V., Butt, E., 2012. Lessons from community-based payment for ecosystem service schemes: from forests to rangelands. Philosophical Transactions of the Royal Society B: Biological Sciences. 367, 3178-3190. 
Edwards, D., Fisher, B., Boyd, E., 2010. Protecting degraded rainforests: enhancement of forest carbon stocks under REDD+. Conservation Letters. 3, 313-316.

Fry, I., 2008. Reducing Emissions from Deforestation and Forest Degradation: Opportunities and Pitfalls in Developing a New Legal Regime. Review of European Community \& International Environmental Law. 17, 166-182.

Gilberthorpe, E., Banks, G., 2012. Development on whose terms?: CSR discourse and social realities in Papua New Guinea's extractive industries sector. Resources Policy. 37, 185-193.

Gillenwater, M., Broekhoff, D.,Trexler, M., Hyman, J., Fowler, R., 2007. Policing the Voluntary Carbon Market. Nature Reports Climate Change. 6, 85-87.

Glenday, J., 2006. Carbon storage and emissions offset potential in an East African tropical rainforest. Forest Ecology and Management. 235, 72-83.

Grassi, G., Monni, S., Federici, S., Achard, F., Mollicone, D., 2008. Applying the conservativeness principle to REDD to deal with the uncertainties of the estimates. Environmental Research Letters. 3, 035005. DOI:10.1088/1748-9326/3/3/035005.

Grist, N., 2008. Positioning climate change in sustainable development discourse. Journal of International Development. 20, 783-803.

Grossman, R.B., Reinsch, T.G., 2002. The Solid Phase - Bulk Desnity and Linear Extensibility, in: Dane J.H., Topp, G.C. (Eds.), Methods of Soil Analysis Part 4 - Physical Methods. Soil Science Society of America and American Society of Agronomy, Madison, Wisconsin, USA, pp 201-225.

Guo, L., Gifford, R., 2002. Soil carbon stocks and land use change: a meta-analysis. Global Change Biology. 8, 345-360.

Hansen, C.P., Lund, J.F., Treue, T. 2009. Neither fast, nor easy: the prospect of Reducing Emissions from Deforestation and Degradation (REDD) in Ghana. International Forestry Review. 11, 439-455

Hilson, G., Nyame, F., 2006. Gold mining in Ghana's forest reserves: a report on the current debate. Area. 2, 175-185.

Hughes, R.F., Kauffman, J.B., Cummings, D.L., 2002. Dynamics of Aboveground and Soil Carbon and Nitrogen Stocks and Cycling of Available Nitrogen along a Land-use Gradient in Rondônia, Brazil. Ecosystems. 5, 244-259.

International Council on Mining and Minerals (ICMM), 2013. ICMM launches series of climate change reports. Available online: http://www.icmm.com/page/93483/news-andevents/news/articles/icmm-launches-series-of-climate-change-reports [Accessed: 24.06.13].

Jandl, R., Lindner, M., Vesterdal, L., Bauwens, B., Baritz, R., Hagedorn, F., Johnson, D., Minkkinen, M., Byrne, K., 2007. How strongly can forest management influence soil carbon sequestration? Geoderma. 137, 253-268.

Kinzig, A.P., Perrings, C., Chapin III, F.S., Polasky, S., Smith, V.K., Tilman, D., Turner, B.L., 2011. Paying for Ecosystem Services. Science. 334, 603-604. 
Konisky, D., 2007. Regulatory Competition and Environmental Enforcement: Is There a Race to the Bottom? American Journal of Political Science. 51, 853-872

Laurence, D., 2007. Optimisation of the mine closure process. Journal of Cleaner Production. 14, 285-298.

Lindsell, J.A., Klop, E., 2013. Spatial and temporal variation of carbon stocks in a lowland tropical forest in West Africa. Forest Ecology and Management. 289, 10-17.

Matthews, J.A., 2008. Carbon-negative biofuels. Energy Policy. 36, 940-945.

Olsen, N., Bishop, J., Anstee, S., 2011. Exploring ecosystem valuation to move towards net positive impact on biodiversity in the mining sector. IUCN and Rio Tinto Technical Series No. 1. IUCN, Switzerland and Rio Tinto, London.

Ostrom, E., 2009. A general framework for analysing sustainability of social-ecological systems. Science. 325, 419-422.

Pellegrinoa, C., Lodhia, S., 2012. Climate change accounting and the Australian mining industry: exploring the links between corporate disclosure and the generation of legitimacy. Journal of Cleaner Production. 36, 68-82.

Putz, F., Redford, K., 2009. Dangers of carbon-based conservation. Global Environmental Change. 19, 400-401.

Robertson, G.P., Coleman, D.C., Bledsoe, C.S., Sollins, P., 1999, Standard Soil methods for long-term ecological research, Oxford University Press, Oxford.

Rowell, D.L., 1994. Soil Science - Methods and Applications. Longman, Harlow, UK.

Ruggie, J.G., 2007. Business and Human Rights: The Evolving International Agenda. The American Journal of International Law. 101, 819-840.

Sandbrook, C., Nelson, F., Adams, W., Agrawal, A., 2010. Carbon, Forests and the REDD Paradox. Oryx. 44, 330-334.

Shrestha, R., Lal, R., 2006. Ecosystem carbon budgeting and soil carbon sequestration in reclaimed mine soil. Environment International. 32, 781-796.

Shrestha, R.K., Lal, R., 2010. Carbon and nitrogen pools in reclaimed land under forest and pasture ecosystems in Ohio, USA. Geoderma. 157, 196-205.

Simpson, W.T., 1996. Method to Estimate Dry-Kiln Schedules and Species Groupings: Tropical and Temperate Hardwoods. Forest Products Laboratory, United States Department of Agriculture, Forest Service, Madison, WI , USA.

Sollins, P., Glassman, C., Eldor, P.A. Sawston, C., Lajtha, K., Heil, J.W., Elliott, E.T., 1999. Soil Carbon and Nitrogen - Pools and Fractions. In: Standard Soil Methods for Long-Term Ecological Research. (G.P. Robertson, D.C. Coleman, C.S. Bledsoe, and P. Sollins,) eds. Oxford, Oxford University Press. 
Sperow, M. 2006. Carbon Sequestration at Reclaimed Mine Sites in Seven East-Central States. Journal of Environmental Quality. 35, 1428-1438.

Stern, N., 2006. The Economics of Climate Change - The Stern Review. Cambridge University Press, Cambridge, UK.

Tan, Z., Tieszen, L.L., Tachie-Obeng, E., Lio, S., Dieye, A.M., 2009. Historical and simulated ecosystem carbon dynamics in Ghana: land use, management, and climate. Biogeosciences. 6, 45-58.

Throop, H.L., Archer, S.R., Monger, H.C., Waltman, S., 2012. When bulk density methods matter: Implications for estimating soil organic carbon pools in rocky soils. Journal of Arid Environments. 77, 66-71.

Ussiri, D., Lal, R., 2005. Carbon Sequestration in Reclaimed Minesoils. Critical Reviews in Plant Sciences. 24, 151-165.

Usuga, J., Toro, J., Alzate, M., Tapias, A., 2010. Estimation of biomass and carbon stocks in plants, soil and forest floor in different tropical forests. Forest Ecology and Management. 260, 1906-1913.

Wade, A.S.I., Asase, A., Hadley, P., Mason, J., Ofori-Frimpong, K., Preece, D., Spring, N., Norris, K. 2010. Management strategies for maximizing carbon storage and tree species diversity in cocoagrowing landscapes. Agriculture, Ecosystems \& Environment. 138, 324-334.

Wauters, J.B., Coudert, S., Grallien, E., Jonard, M. Ponette, Q. 2008. Carbon Stock in rubber tree plantations in Western Ghana and Mato Grosso (Brazil). Forest Ecology and Management. 255, 2347-2361.

Whitmore, A., 2006. The emperors new clothes: Sustainable mining? Journal of Cleaner Production. 14, 309-314. 